\title{
Is ICT Mediated Brain Based Teaching a Real Escalating Modus Operandi in Teaching Mathematics
}

\author{
M. Raghavendran, A. Jahitha Begum
}

\begin{abstract}
The objective of the study is to scrutinize the effect of the organized teaching that designed in accordance with the principles of Brain Based Teaching mediated by Information and Communication Technology (ICT) Tools on enhancing the Problem Solving Ability in Mathematics of School Students. Control Group Pre-Test Post-Test Experimental Design has been applied in the study. The research revealed that Brain Based Teaching environment mediated by ICT Tools has a deep positive impression on enhancing the Problem Solving Ability in Mathematics amidst school students.
\end{abstract}

Index Terms - Brain Based Teaching, ICT, Problem Solving Ability, Relaxed Alertness, Orchestrated Immersion, Active Processing.

\section{INTRODUCTION}

Educators face many complex problems now-a-days in their teaching profession. Every educator has to know how learning occurs in brain to maximize learning process of their students. Knowledge of how human brain learns is a deciding factor of the success of the teaching profession. Brain Based Teaching can provide such a perspective [1]. ICT Tools are the gateway of easing learning.

\section{A. Brain Based Teaching}

Brain Based Teaching is coined in such a way that suits most effective way of the brain's learning mechanism [2]. It goes parallel to the natural way of how our brain learns. Recognition of the codes of human brain and making learning meaningful and adjusting to those codes is the main aim of Brain Based Teaching. Brain Based Teaching is a motivating, positive way of maximizing teaching and learning. It is based on the best way our brain learns.

Reference [3]'s teaching strategies provide a brilliant explanation of Brain Based Teaching and its significance as follows:

- B- Brain's Time Clock - Keep Rhythm by alternating spatial and verbal tasks

- $\quad$ R- Repitition- Use previewing and reviewing strategies

- $\quad$ Active Learning- Increase blood flow with physical movement

- I- Images- Enrich the visual learning environment

- N- Novelty- Stimulate the brain with new approaches
- B- Be Colourful- Facililtate retention and motivation by colour-coding

- A-Automatic Learning- Recognise the influence of non-verbal communication

- S - Social Brain- Exploit opportunities for cooperative learning

- E- Elicit Emotions- Create Opportunities for emotional engagement

- D- Developing Thinking skills- Engage learners in problem solving

Reference [4] devised 12 principles of Brain Based Learning as follows:

- $\quad$ All learning engages physiology

- The brain is social

- The search for meaning is innate

- $\quad$ The search for meaning occurs through patterning

- Emotions are critical to patterning

- The brain processes parts and wholes simultaneously

- Learning involves both focusses attention and peripheral perception

- Learning always involves conscious and unconscious processes

- We have at least two ways of organising memory: spatial and rote

- $\quad$ Learning is developmental

- Complex learning is enhanced by challenge and inhibited by threat

- $\quad$ Each brain is unique.

Three main interactive teaching elements elicited from the above principles. They are

1. Relaxed Alertness,

2. Orchestrated Immersion in complex exposures,

3. Active Processing

B. Why Brain Based Teaching?

Many educators argue that as every teaching is based on activities of brain, where is the necessity of Brain Based Teaching? It is the way of understanding how the brain works best naturally and how we can increase the learning to the optimal level. So every educators' wish will be fulfilled by maximizing the attainment in their corresponding subjects. Last 15 years or so, neuroscientists are doing research on brain and its working system through

\footnotetext{
Revised Manuscript Received on September 14, 2019.

M. Raghavendran, Ph.D., Research Scholar, School of Education, The Gandhigram Rural Institute - Deemed to be University, Gandhigram, Tamil Nadu, India.(E-mail: rva.vignesh@gmail.com)

Dr. A. Jahitha Begum, Research Supervisor, Professor and Head, School of Education, The Gandhigram Rural Institute - Deemed to be University, Gandhigram, Tamil Nadu, India.(E-mail: jahee_j@yahoo.com)
} 
researches via MRIs, EEGs, PET and CAT scans and its evident that Brain Based Teaching is visible via these scanning technologies.

Many studies have been conducted based on Brain Based Teaching approach with English composition, learning process and teaching methods, Religious education, Science education, Social Studies, attitude, Mathematics at Higher education.

Even though various researches were conducted on Brain Based Teaching approach with various academic, psychological subjects, no many researches have been done in Mathematics that too at school level so far. School mathematics is base for the higher education. So the researchers wanted to determine the effect of Brain Based Teaching approach on enhancing the Problem Solving Ability in Mathematics among Eighth standard students in this study.

\section{ICT}

Educational reforms occur throughout the world using ICT. Information Technology and Communication Technology, since its inception, proved its effectiveness in various fields of modern human life. ICT has its impacts in the field of education, especially in the teaching-learning process. Every teacher's wish and will is the fullest attainment or achievement of the learning skills taught in his/ her class. Nowadays teachers search for the supportive items that complement or boost their teaching, for increasing the attainment of the subject. The introduction and integration of ICT in the educational system for the recent past years boosted the educational outcomes in various perspectives. ICT embraces and adapts all the main principles revealed by the learning theories, as a result, educational outcomes are automatically boosted up with the conceptual understanding of the subjects taught. The relevance and the impact of ICT in the teaching and learning process is inevitable in this Knowledge Era of the Information Age. ICT is a specific term that refers to technologies made for the collection, processing, preserving, and delivering information [5]. ICT affects every walk of life, a must, and factors of change in society [6]. ICT is an effective means for addressing educational goals and requirements. Almost all of the educators who use ICT in education is only for increasing academic achievement or performance. Unknowingly or indirectly there are many abilities, skills, procedures, rules are created while we use ICT in Mathematics education. So studying the versatility of ICT in the education process is important for educators in addition to the direct outputs. Academically it's important to know the usefulness, the role played by ICT in mathematics because most of the developing countries are using ICT in the Teaching-Learning process. In this article, you can expect the indirect or by-products skills developed by ICT while learning mathematics using it.

\section{Why ICT}

ICT has an impact on all walks of human life. Though it has been used in various fields, the field of education is the emerging one worldwide. Well-developed countries have made the use of ICT in a better way whereas the developing nations are still in the initial stage. Due to a boom in communication technology nowadays, ICT can be made use of in the educational sector. Center for Technology in Learning, UK (CTL-UK) identified Computational purpose, Representational purpose as two reasons for why one should use technology in the mathematics classroom.

One of the UNESCO's aims is to provide all the technological facilities to prepare the young generation, in turn, they will contribute to a knowledge nation worldwide. UNESCO advised all the nations on the optimal balance between ICT and conventional teaching technologies which will ensure to achieve the goal 'Education for All' (EFA). The main aim of education is for social change. ICT can be a factor of social change if properly utilized in the school education sector. The educational system can decide and eradicate the negative impact on ICT. The education sector makes use of ICT by implementing the strategy to make teaching and learning most effective. ICT is not just the byproduct of educational activities but also it is the secondary option to improve education [7]. ICT enables greater collaboration between pupils, enhances the power of interpretation. It provides fast feedback and that too accurately. Effective implementation of ICT in education enables the students to know the learning objectives explicitly. ICT helps in the learning process as well as in the organization of learning, instruction, along with reading, writing, and numeracy, ICT literary had its place [8]. The integration of ICT in teaching enhances students' learning [9]. ICT changes the tempo of the lesson and offers various ways to approach a lesson and coping with the growing Research and Development in the field of education regarding ICT usage.

ICT can be treated as an effective tool and construction of concepts in mathematics concerning the purpose [10] Mathematical knowledge and mathematical practices are indispensably linked and that link is strengthened by ICT. Mathematics is a difficult, abstract, complex subject. Topics in this subject may make students feel sacred, bored. Working with dynamic images and manipulating diagrams encourage students to visualize through their mental images ICT provides a great opportunity for students to work with data presented in various ways [11]. This tendency creates pressure on the teachers of mathematics and teachers can change this tendency in primary and upper primary/ intermediate students which are necessary for their life. ICT is an essential tool for learning mathematics. National Council of Teachers of Mathematics [12] stressed the importance of the central role played by ICT in maths learning and asked every school should ensure it in all schools [13]. ICT in teaching-learning mathematics may be grouped as (i) a tool for doing maths (ii) fostering of learning for practicing skills (iii) fostering the conceptual understanding [14].

ICT integrates mathematics with an authentic context that leads to meaningful learning and contextual learning [15]. It makes it easy to create, manage and share the images that are created by using computers while teaching mathematics, 
hence understanding of mathematical concepts are easy [16]. ICT makes students free to focus on strategies through trial and error method [17], [18], [19]. The communication and representational skills through images, graphing, text students are automatically increased where ICT is properly used among school students [18]. ICT swifts up the graphing, plotting process and reflects on the relationships between data [20]. By resorting, reordering data in different ways, ICT helps in exploring problems [17]. Students can make their representation correctly through ICT [21]. Multimedia software program increases the learning of mathematics among learning and cognitive disability students. Video Conferencing also played a vital role in learning mathematics by helping meet state and national curriculum standards, enhancing technical and content skills, take mathematics to their home [22].

\section{PURPOSE OF THE STUDY}

In this study, the effects of teaching in accordance with the Brain Based Teaching approach mediated by ICT Tools on enhancing the Problem Solving Ability in Mathematics among Eighth standard students was examined to establish if there is any difference comparing to Conventional Teaching Approach.

\section{A. Research Questions}

Following are the research questions of the present study

1. Does Brain Based Teaching approach have impact on enhancing the Problem Solving Ability in Mathematics among Eighth standard students?

2. Does ICT Tools have impact on enhancing the Problem Solving Ability in Mathematics among Eighth standard students?

3. Is there any difference between Brain Based Teaching approach and the Conventional Teaching Approach in Teaching Problem Solving Ability in Mathematics?

4. Is there any difference between the Control and Experimental Group with regard to the Problem Solving Ability in Mathematics?

5. Is there any difference between the Control and Experimental Group with regard to the ICT mediated Brain Based Teaching?

\section{METHODS}

Quanitative Techniques are used in this study. Quasi Experimental Design has been used in this research. Brain Based Teaching, Usage of ICT tools and Problem Solving Ability in mathematics score averages of students in the Experimental and Control groups have been compared.

\section{A. Participants}

Convenience Sampling was adopted to choose sample in this study. The research has been conducted on a Control and Experimental Group comprising 30 students in each group of $8^{\text {th }}$ standard from Panchayat Union Middle School, Gundalahalli, Karimangalam Block, Dharmapuri district (Experimental Group) and Panchayat Union Middle School, Genguchettipatti, Karimangalam block, Dharmapuri district (Control Group). Trained Teachers from each school has been set for teaching purpose. In order to establish the equivalence of the groups, the maturity level, background, age, training, academic scores have been compared with independent $t$ test and the groups have been found to be equivalent on measure. Both the groups had Low, Moderate and High level of achievers, equally divided.

\section{B. Instruments}

In this research, data collection tools were Achievement Test in Problem Solving Ability in Mathematics 20 items each having 2.5 marks for all the questions totally having 50 marks and Pre-test was conducted to both the groups for measuring knowledge, comprehension, application, problem solving ability. A Scoring key was prepared by the researchers. Validity of test was established using item analysis. A Check list of Brain Based Teaching factors, which consists of 50 questions each having 1 mark for yes and 0 mark for no with regard to positive item and reverse procedure to scoring negative items. The Checklist had 9 domains and had 18 negative questions and 32 positive questions, developed by the researchers. A Check list of the Usage of ICT Tools, which consists of 75 questions each having 1 mark for yes and 0 mark for no with regard to positive item and reverse procedure to scoring negative items. The Checklist had 10 domains and had 15 negative questions and 60 positive questions, developed by the researchers. The Check list of Brain Based Teaching and Usage of ICT Tools were validated by corresponding subject experts. Brain Based Teaching Module was prepared by the researchers.

\section{Experimental Process}

The research was conducted for six weeks continuously. Conventional method was taught as teaching approach for Control Group students. On the other hand the teaching approach based on the Brain Based Teaching mediated by ICT Tools applied to the Experimental Group. Some specialized features of Brain Based Teaching are as follows

- All possible lessons have been integrated

- Rich resource has been provided with technological support

- Brain Based Learning environment is provided such that individual opinions are developed

- $\quad$ No threatening situation was provided

- Colourful, Pleasing class environment with giving importance to music as a part of lesson

- $\quad$ Play Based Activities with direct experience

- Participation of all students in all activities

- $\quad$ Students working together was a rule

- Emotions and feeling of students were given importance

- $\quad$ Concept maps, Direct learning, Graphics, Problem

- Solving Activities have been provided for Experimental group

- $\quad$ Real life content were provided

As soon as the experimentation period was over, both the groups were administered a Problem Solving Ability Post Test. 


\section{ANALYSIS AND INTERPRETATION}

After the experimentation process, the date obtained from the tests were analysed to determine the effect of Brain Based Teaching mediated by ICT Tools on enhancing Problem Solving Ability in Mathematics of the experimental group students. Mean scores, Standard Deviation of marks obtained in the Pre, Post Tests and Brain Based Teaching Check list administered to both the groups in the post test were calculated. Results from 't' test, Pearson's Correlation Analysis were used to compare the Problem Solving Ability of the Experimental and Control Group. The SPSS 22.0 was used to analyse the data and $\mathrm{p}$ value was determined to $1 \%$, $5 \%$ level of confidence.

\section{A. Findings}

Frequency Distribution of Gender of the Students

\begin{tabular}{lllll}
\hline S.No. & Group & Gender & Frequency & Percentage \\
\hline \multirow{2}{*}{1.} & $\begin{array}{l}\text { Experimental } \\
\text { Group }\end{array}$ & Boys & 16 & 53 \\
\cline { 3 - 5 } & Girls & 14 & 46 \\
\hline \multirow{2}{*}{2.} & $\begin{array}{l}\text { Control } \\
\text { Group }\end{array}$ & Boys & 9 & 30 \\
\cline { 3 - 5 } & Girls & 21 & 70 \\
\hline
\end{tabular}

Each group had 30 students each. The Experimental Group had 16 boys and 14 girls and the Control Group had 9 boys and 21 girls.

\begin{tabular}{lllll}
\multicolumn{5}{c}{ Frequency Distribution of Level of Achievers } \\
of Students
\end{tabular}

Both the Control and the Experimental Groups had 10 students each at every levels viz., Low, Moderate, High Achieving groups.

- $\quad$ Research Question: Is there any significant difference between Control Group and Experimental Group of Pre-Test in Problem Solving Ability in Mathematics among students?

t test for significant difference between Control and Experimental Group of Pre-Test in Problem Solving Ability in Mathematics of students

\begin{tabular}{lllll}
\hline \multirow{4}{*}{ Group } & \begin{tabular}{l} 
Pre-Test $\begin{array}{l}\text { of } \\
\text { Problem } \\
\text { Ability } \\
\text { Mathematics }\end{array}$ \\
\cline { 2 - 3 } in
\end{tabular} & t value & P value \\
\cline { 2 - 3 } Mean & SD & & \\
\hline Control Group & 53.43 & 11.51 & 0.167 & \multirow{2}{*}{0.868} \\
\hline Experimental Group & 52.99 & 8.90 & & \\
\hline
\end{tabular}

From the above table, since $\mathrm{P}$ value is 0.868 , it is concluded that there is no significant difference between the control and Experimental group of Pre-test in Problem Solving Ability in Mathematics.

- Research Question: Is there any significant difference between Control Group and Experimental Group with regard to the factors of Brain Based Teaching in Mathematics among students?

t test for significant difference between Control and Experimental Group with respect to the factors of Brain

Based Teaching of Mathematics students

\begin{tabular}{|c|c|c|c|c|c|c|}
\hline \multirow{3}{*}{$\begin{array}{l}\text { Factors of } \\
\text { Brain Based } \\
\text { Teaching }\end{array}$} & \multicolumn{4}{|l|}{ Group } & \multirow{3}{*}{$\begin{array}{l}\text { t } \\
\text { value }\end{array}$} & \multirow{3}{*}{$\begin{array}{l}\mathbf{P} \\
\text { value }\end{array}$} \\
\hline & \multicolumn{2}{|c|}{$\begin{array}{l}\text { Control } \\
\text { Group }\end{array}$} & \multicolumn{2}{|c|}{$\begin{array}{l}\text { Experimental } \\
\text { Group }\end{array}$} & & \\
\hline & Mean & SD & Mean & SD & & \\
\hline Uniqueness & 2.17 & 0.38 & 5.37 & 0.49 & 28.288 & $\begin{array}{l}<0.001 \\
* *\end{array}$ \\
\hline Meaning & 3.53 & 0.63 & 6.63 & 1.13 & 13.139 & $\begin{array}{l}<0.001 \\
* *\end{array}$ \\
\hline Multipurpose & 2.10 & 0.31 & 4.63 & 0.49 & 24.033 & $\begin{array}{l}<0.001 \\
* *\end{array}$ \\
\hline Emotions & 2.27 & 0.45 & 4.47 & 0.51 & 17.771 & $\begin{array}{l}<0.001 \\
* *\end{array}$ \\
\hline $\begin{array}{l}\text { Brain Body } \\
\text { Relationship }\end{array}$ & 2.50 & 0.57 & 6.13 & 0.94 & 18.123 & $\begin{array}{l}<0.001 \\
* *\end{array}$ \\
\hline $\begin{array}{l}\text { Memory } \& \\
\text { Learning }\end{array}$ & 1.27 & 0.45 & 2.77 & 0.43 & 13.201 & $\begin{array}{l}<0.001 \\
* *\end{array}$ \\
\hline $\begin{array}{l}\text { Cycle and } \\
\text { Rhythms }\end{array}$ & 1.37 & 0.49 & 3.50 & 0.51 & 16.544 & $\begin{array}{l}<0.001 \\
* *\end{array}$ \\
\hline $\begin{array}{l}\text { Elimination } \\
\text { of Threat }\end{array}$ & 1.53 & 0.57 & 4.47 & 0.51 & 21.026 & $\begin{array}{l}<0.001 \\
* * \\
\end{array}$ \\
\hline Assessment & 2.70 & 0.70 & 5.80 & 1.22 & 12.100 & $\begin{array}{l}<0.001 \\
* *\end{array}$ \\
\hline
\end{tabular}

\begin{tabular}{|c|c|c|c|c|c|c|}
\hline $\begin{array}{l}\text { Overall } \\
\text { Usage of } \\
\text { Brain Based } \\
\text { Teaching }\end{array}$ & 1.943 & 2.41 & 43.77 & 4.03 & 28.355 & $\begin{array}{l}<0.001 \\
* *\end{array}$ \\
\hline
\end{tabular}

From the above table value, since $\mathrm{P}$ value is less than 0.001 for all the nine factors and the overall usage factor, it is evident that there is a significant difference between Control and Experimental Group students with regard to the Factors of Brain Based Teaching. So it is the Experimental Group which was taught through Brain Based Teaching had more mean value than the Control Group with regard to all of the nine factors.

Research Question: Is there any significant relationship among the factors of Usage of ICT Tools and Problem Solving Ability in Mathematics of Experimental Group students? 
Pearson's Correlation Co-efficient between the factors of Usage of ICT Tools and Problem Solving Ability in

Mathematics of Experimental Group students

\section{Correlation}

Factors of Usage Type of Test in Problem Solving of ICT Tools of Ability in Mathematics

Experimental Group

Pre- Post- Gain Test Test Percentage

\begin{tabular}{llll} 
Instructive & $0.418^{*}$ & $0.502^{* *}$ & 0.146 \\
\hline Communicative & 0.239 & $0.564^{* *}$ & $0.372^{*}$ \\
\hline Organisational & 0.224 & $0.721^{* *}$ & $0.548^{* *}$ \\
\hline
\end{tabular}

\begin{tabular}{llll} 
Programming & 0.283 & $0.683 * *$ & $0.455^{*}$ \\
\hline Recreational & 0.129 & $0.618^{* *}$ & $0.526 * *$
\end{tabular}

\begin{tabular}{llll}
\hline Expansive & 0.281 & $0.497 * *$ & 0.264 \\
\hline Creative & 0.299 & $0.596 * *$ & 0.350 \\
\hline
\end{tabular}

$\begin{array}{llll}\text { Expressive } & 0.521 * * & 0.545^{* *} & 0.990\end{array}$

$\begin{array}{llll}\text { Evaluative } & 0.260 & 0.362 * & 0.143\end{array}$

Informative $\quad 0.489 * * \quad 0.594 * * \quad 0.146$

\section{Overall Usage of ICT Tools

$0.483 * * \quad 0.859 * * \quad 0.459 * *$

The correlation co-efficient between the factor of Usage of ICT Tool viz., Instructive and Post-test score of Problem Solving Ability in Mathematics is 0.502, which means 50.2 percentage of positive correlation exists between Instructive and Post-test score of Problem Solving Ability in Mathematics and is significant at $1 \%$ level. The correlation co-efficient between the factor of Communicative and Posttest score of Problem Solving Ability in Mathematics is 0.564 , which means 56.4 percentage of positive correlation exists between Communicative and Post-test score of Problem Solving Ability in Mathematics and is significant at $1 \%$ level.

Research Question: Is there any significant relationship among the factors of Brain Based Teaching and Problem

Solving Ability in Mathematics of Experimental Group students?

Pearson's Correlation Co-efficient between the factors of Brain Based Teaching and Problem Solving Ability

in Mathematics of Experimental Group students Correlation

Factors of Brain Type of Test in Problem Solving

Based Teaching of Ability in Mathematics

Experimental Group Pre- Post- Gain

\begin{tabular}{llll} 
& Test & Test & Percentage \\
\hline Uniqueness & $0.460^{*}$ & $0.482^{* *}$ & 0.088 \\
\hline Meaning & $0.465^{* *}$ & $0.657^{* *}$ & 0.265 \\
\hline Multipurpose & $0.587^{* *}$ & $0.441^{*}$ & 0.069 \\
\hline Emotions & $0.531^{* *}$ & $0.389^{*}$ & 0.073 \\
\hline $\begin{array}{l}\text { Brain } \\
\text { Relationship }\end{array}$ & 0.259 & $0.495^{* *}$ & 0.282 \\
\hline Memory \& Learning & 0.246 & $0.374^{*}$ & 0.168 \\
\hline Cycle and Rhythms & $0.461^{*}$ & $0.645^{* *}$ & 0.257 \\
\hline Elimination of Threat & 0.304 & $0.369^{*}$ & 0.110 \\
\hline Assessment & $0.393^{*}$ & $0.676^{* *}$ & 0.349
\end{tabular}

Overall Usage of

$\begin{array}{lllll}\text { Brain } & \text { Based } & 0.626 * * & 0.832 * * & 0.302\end{array}$

Teaching

** Denotes Significant at $1 \%$ level

* Denotes Significant at $5 \%$ level

From the above Pearson's Correlation table, Overall Usage of Brain Based Teaching has better correlation in both the Pre-test and the Post-test, it is evident that the Problem Solving Ability in Mathematics is enhanced by the factors of Brain Based Teaching.

- Research Question: Is there any significant difference between Control Group and Experimental Group of Post-Test with regard to Problem Solving Ability in Mathematics among students?

t test for significant difference between Control and Experimental Group of Post-Test in Problem Solving Ability in Mathematics of students

\begin{tabular}{|c|c|c|c|c|}
\hline Group & $\begin{array}{l}\text { Post-Test } \\
\text { Problem } \\
\text { Ability }\end{array}$ & $\begin{array}{r}\text { of } \\
\text { Solving }\end{array}$ & \multirow[t]{2}{*}{$\begin{array}{l}\mathrm{t} \\
\text { value }\end{array}$} & \multirow[t]{2}{*}{$P$ value } \\
\hline & Mean & SD & & \\
\hline Control Group & 54.09 & 11.62 & \multirow{2}{*}{8.742} & \multirow{2}{*}{$<0.001 * *$} \\
\hline $\begin{array}{l}\text { Experimental } \\
\text { Group }\end{array}$ & 78.87 & 10.29 & & \\
\hline
\end{tabular}

** Denotes Significant at $1 \%$ level

From the above table since $\mathrm{P}$ value is less than 0.001 , it is concluded that there is a significant difference between the Control and Experimental Group students' Post -test scores of Problem Solving Ability in Mathematics. 


\section{DISCUSSION \& IMPLICATIONS \& RESULTS}

These findings depicted that there was a great contribution of Brain Based Teaching mediated by ICT Tools on enhancing the Problem Solving Ability in mathematics among eighth standard students because Brain Based Teaching with ICT tools focus on every individual students' learning and importance to the process of learning. Brain Based Teaching with ICT Tools always coincides with the natural way of learning that occur in the neurons of the brain. Brain Based Teaching with ICT Tools focus at the higher level thinking skills, Problem Solving Ability...etc as well as the transfer of knowledge. It focuses on the thought process, intuitional thinking...etc. Brain Based Teaching organizes learning as internalization and ICT Tools emphasize on meaningful learning rather than rote learning.

From the findings of the study, the Brain Based Teaching mediated by ICT Tools appears to be more effective than the conventional method on enhancing the Problem Solving Ability in Mathematics. It is parallel to the result of [23] in Social Studies, [24] in Science courses, [25] in Science, [26] in Social Studies, [27] in Biology education, [28] in Science, [29] in English as a Foreign language, [30] in Mathematics, [31], [32] in Academic Achievement.

\section{CONCLUSION}

This study explored the effect of Brain Based Teaching mediated by ICT Tools on Problem Solving Ability in Mathematics among Eighth standard students. With the evidences gathered through quantitative method, it is clear that Brain Based Teaching with ICT Tools has significant effect on Problem Solving Ability in Mathematics. So we can come to a conclusion that students who were taught using the Brain Based Teaching approach mediated by ICT Tools had a better Problem Solving Ability in Mathematics comparing to the conventional teaching approach.

\section{A. Recommendations for Further Studies}

From the results of this study,

- Brain Based Teaching with ICT Tools may be adapted for Mathematics for all classes in order to enrich the academic success and retention rate of the previously learnt subjects.

- Brain Based Teaching with ICT Tools Module prepared for this study may be followed for all the classes and for all the subjects.

- In service training on Brain Based Teaching approach with ICT Tools may be provided for all the working teachers as it is effective.

- Necessary funding to Government Schools for adapting Brain Based Teaching approach with ICT Tools and infrastructure facilities may be provided

- A module on Brain Based Teaching Principles and Work Sheets, Activities may be prepared and provided to teachers.

- $\quad$ Prospective teachers may be trained in Brain Based Teaching techniques and ICT Tools may consider as a part of curriculum.

- Cognitive Neuroscience may be inculcated in the teacher educator programme with proper training in ICT Tools.
- $\quad$ Short-term, Certificate, Online courses on Brain based Teaching with ICT Tools may be provided to teachers.

For further researches following points may be considered. Studies can be done on the following areas such as Effect of Brain Based Teaching on ICT Tools and on Attitude toward all subjects at all level of education, Effect of Brain Based Teaching on Higher Order Thinking Skills, Effect of Brain Based Teaching on Self-Regulated Activities, Effect of Brain Based Teaching of Essential Regulatory Skills, Effect of Brain Based Teaching on Retention, Effect of Brain Based Teaching on Meta Cognition...etc may be concentrated in future.

\section{REFERENCES}

1 T. Tokuhama-espinosa, "why mind, brain, and education science is the new brain based education," new horizons in education, pp. 1-10, january 2011.

2 E. Jensen, teaching with the brain in mind, virginia, usa: association for supervision and curriculum development, 2005.

3 S. Hileman, "motivating students using brain based teaching strategies," the agricultural education magazine, vol. 78, no. 4, pp. 18-20, 2006.

4 R.n.caine and g. Caine, 12 brain/ mind learning principles in action: the field book for making connections, thousand oaks, california: corwin press, 2005.

5 M. J. Elisha, "the applicaiton of information and communication technology (ict) in nigerian academic libraries prospects and problems," information manager, vol. 6, no. 1, pp. 35-39, 2006.

6 D. Zhang and 1. Liu, "how does ict use influence students' achievements in math and science over time? Evidence from pisa 2000 to 2012.," eurasia journal of mathematics, science and technology education, vol. 12, no. 9, pp. 2431-2449, 2015.

7 Meenakshi, "importance of ict in education," iosr journal of research and methods in education, vol. 1, no. 4, pp. 38, 2013.

8 Pisa, "programme for international student assessment report 2015," oecd publications, paris, 2015.

9 Bransford.et.al., how people learn: brain, mind, experience and school, washington dc: national academy press, 1999.

10 J. Olive and k. Makar, "mathematical knowledge and practices resulting from access to digital technologies," in mathematics education and technology - rethinking the terrain - the 17th icmi study, new york, 2010.

11 M. Barve and v. Barve, "role of technology in teaching and learning mathematics," in national meet on celebration of national year of mathematics, new delhi, 2012.

12 Nctm, principles and standards for school mathematics, reston, va: key curriculum press, 2000.

13 P. Pannen, "integrating technology in teaching and learning mathematics," 05 may 2015. [online]. Available: http;//cdn.nmc.org/media/2014.

14 P. Drijvers, p. Boon and v. Reeuwijk, "algebra \& technology," in in p.drijvers (ed.) Secondary algebra education, rotterdam, 2010. 
15 R. Amarasinghe and d. Lambdin, "uses of computer technology in interdisciplilnary mathematics learning," in international conference on learning with technology, philadelphia, 2000.

16 M. Joubert, "the impact of ict on mathematical concepts," in the british society for research into learning mathematics, london, 2008.

17 Clements.d.h, "from excercises and tasks to problems and projects: unique contribution of computers to innovative mathematics education," the journal of mathematics behaviour, vol. 19, no. 1, pp. 9-47, 2000.

18 D. Jarrett, "integrating technology into middle school mathematics: it's just good teaching," northwest regional educational laboratory, 1998.

19 Ruthven.k and hennessy.s, "a practitioner model of the use of computer based tools and resources to support mathematics teaching and learning," educational studies in mathematics, vol. 49, no. 1, pp. 47-88, 2002.

20 S. Hennessy and p. Dunham, "equity issues affecting mathematics learning using ict," research in mathematics education, vol. 4, pp. 145-165, 2002.

21 Sivasubramaniam.p, "distributed cognition, computers and the interpretation of graphs," research in mathematics education, vol. 2, pp. 169-180, 2000.

22 C. Irish, "using peg and keyword mnemonics and computer assisted instructions to enhance basic multiplication performance in elementary students with learning and cognitive disabilities," journal of special education technology, vol. 17, no. 4, pp. 29-40, 2002.

23 T. Cengelci, "the effects of brain based learning to success and retention in social studies," unpublished master's thesis, eskisehir, 2005.

$24 \mathrm{~J}$.

Wortock, "http://proquest.umi.com/pqdweb?did=765069251," 15 august 2019. [online]. Available: http://www.proquest.umi.com.

25 M. Ozden and m. Gultekin, "the effects of brain-based learning on academic achievement and retention of knowledge in science course," electronic journal of science education, vol. 12, no. 1, pp. 1-17, 2008.

26 B. Duman, "the effect of brain based instruction to improve on students' academic achievement insocial studies instruction," in 9th international conference on engineering education, san juan, 2006.

27 S. Aydin and m. Yel, "the effect of brain based learning biiology education upon the academic success and attitude," energy education science and technologysocial and educational studies, vol. 3, no. 1, pp. 87-98, 2011.

28 E. Akyurek, "effects of brain based learning approach on students' motivation and attitudes levels in science class," mevlana international journal of education, pp. 104-119, 2013.

29 M. Haghighi, "the effect of brain based learning of iranian efl learners' achievement and retention," procedia- social and behavioral sciences, pp. 508-516, 2013.

30 Aziz-ur-rehman, "effectiveness of brain-based learning method and conventional method in teaching of mathematics at secondary level in pakistan: an experimental study," islamabad, 2011.

31 J. A. Morgan and m. C. Fonseca, "multiple intelligence theory and foreign language learning; a brain based perspective," international journal of english studies, vol. 4, no. 1, pp. 119-136, 2004.

32 E. Gozuyesil and a. Dikicl, "the effect of brain based learning on academic achievement: a meta-analytical study," educational sciences: theory \& practice, vol. 14 , no. 2, pp. 642-648, 2014. 